\title{
Inovasi dan Kreatifitas UMKM di Masa Pandemi (Studi Kasus: UMKM di Kabupaten Pringsewu)
}

\author{
Khairul Saleh $^{1}$, Novalia $^{1 *}$, Yessy Dekasari ${ }^{1}$, M. Nur Khoiriyansyah ${ }^{1}$ \\ ${ }^{1}$ Universitas Sang Bumi Ruwa Jurai \\ *Correspondence : novaliasholehah@gmail.com
}

\begin{abstract}
Abstrak.
Tujuan penelitian ini adalah untuk mengetahui 1) UMKM mana di Kabupaten Pringsewu dapat bertahan di tengah pandemi Covid-19; 2) bagaimana inovasi dan kreatifitas yang dilakukan UMKM di Kabupaten Pringsewu agar dapat bertahan di tengah pandemi Covid-19. Metode yang digunakan dalam penelitian ini adalah deskriptif kualitatif. Subjek dalam penelitian ini adalah 30 UMKM di Kabupaten Pringsewu. Penelitian dilakukan pada 1 maret sampai tangga1 30 maret 2021. Hasil penelitian diperoleh kesimpulan bahwa dari 30 UMKM yang ada di Pringsewu, ada 7 UMKM yang tidak mampu bertahan dan sisanya masih berusaha bertahan. Hal tersebut selain karena adanya wabah covid-19, para pengusaha ini memang mempunyai kendala da1am permodalan, pengolahan bahan produksi dan penjualan yang diperparah lagi saat kondisi pandemi. Dalam hal Inovasi dan kreatifitas, hal yang dilakukan antara lain berpindahnya cara berjualan dari offline menjadi online di masa pandemi, membuat suatu produk baru yang benar-benar unik, memodifikasikan produk yang menciptakan kualitas dan gaya baru untuk meningkatkan penjualan.
\end{abstract}

Kata kunci: Inovasi, Kreatifitas, Masa Pandemi Covid-19, UMKM

\begin{abstract}
.
The purpose of this study is to find out 1) which MSMEs in Pringsewu Regency can survive in the midst of the Covid-19 pandemic; 2) how are the innovations and creativity carried out by MSMEs in Pringsewu Regency so that they can survive in the midst of the Covid-19 pandemic. The method used in this research is descriptive qualitative. The subjects in this study were 30 MSMEs in Pringsewu Regency. The study was conducted on March 1 to March 30, 2021. The results of the study concluded that of the 30 MSMEs in Pringsewu, there were 7 MSMEs that were unable to survive and the rest were still trying to survive. This is because apart from the Covid-19 outbreak, these entrepreneurs do have constraints in capital, processing of production materials and sales, which are made worse during the pandemic. In terms of innovation and creativity, things that have been done include changing the way of selling from offline to online during a pandemic, creating a new product that is truly unique, modifying products that create new qualities and styles to increase sales.
\end{abstract}

Keywords: Innovation, Creativity, Covid-19 Pandemic Period, MSMEs

\section{PENDAHULUAN}

Diawal tahun 2020 ini Virus Covid-19 atau Corona merupakan penyakit misterius yang melumpuhkan kota Wuhan, Cina pada akhir tahun 2019 yang akhirnya menyebar luas keseluruh dunia terutama Indonesia sehingga berkembang dan tumbuhnya UMKM di Indonesia kembali diuji ketangguhannya dalam menghadapi dampak ekonomi karena terjadinya penyebaran Covid-19 yang memicu sentiment negative (Munthe \& Rahadi, 2021).

Keberadaan UMKM tidak dapat dihapuskan ataupun dihindarkan dari masyarakat bangsa saat ini. Karena keberadaannya sangat bermanfaat dalam hal pendistribusian pendapatan masyarakat (Ernawati, 2021). Apalagi jumlah UMKM di Indonesia mencapai 64,19 juta, dengan komposisi Usaha Mikro dan Kecil (UMK) sangat dominan yakni 64,13 juta $(99,92 \%)$ dari keseluruhan sektor usaha (Bahtiar, 
2021) termasuk salah satunya Kabupaten Pringsewu. JumIah inilah yang akan meningkatkan penyerapan tenaga kerja (Sukwika, 2018).

berdasarkan SK Kementerian Koperasi dan UMKM Republik Indonesia terdapat 245.136 UMKM yang tersebar di 15 Kabupaten/Kota di Provinsi Lampung (Rohmawati \& Lestari, 2021). Berbagai kebijakan dirancang untuk melindungi dan memulihkan UMKM di tengah pandemic Covid-19. Salah satunya dilakukan pemberian Banpres Produktif Usaha Mikro (BPUM). menerima Bantuan Presiden Produktif untuk Usaha Mikro (BPUM). Pemerintah memberikan bantuan langsung sebesar Rp2,4juta tiap penerima. Bantuan ini diberikan kepada 12 juta pelaku usaha mikro yang tidak sedang menerima bantuan kredit perbankan (Wardiningsih et al., 2021).

Kabupaten Pringsewu merupakan salah satu kabupaten di Provinsi Lampung (Darwis et al., 2020). Kabupaten Pringsewu merupakan saIah satu kabupaten yang memiliki banyak potensi usaha yang mampu bersaing pada pasar domestik maupun mancanegara (Bakhri \& Futiah, 2020). Laju Ekonomi Kabupaten Pringsewu periode 2010 - 2015 dapat dilihat dari laju Pertumbuhan Ekonomi Lampung dan NasionaI. Jika dilihat dari statistic ini, sangat terlihat sekali bahwa LPE (Laju Pertumbuhan Ekonomi) Kabupaten Pringsewu dari periode 2013 sampai dengan 2017 termasuk tinggi apabila dibandingkan dengan LPE Provinsi Lampung dan juga masih dibawah LPE Nasional.

Di masa pandemi ini tentunya membuat dampak yang cukup signifikan di berbagai sektor terutama UMKM di Kabupaten Pringsewu dan menghambatnya pertumbuhan bisnis. Dampak ini sudah terlihat Iangsung dengan adanya pengurangan tenaga kerja (A. P. Wibowo \& Sudiro, 2021), berbagai tindakan dalam antisipasi seperti social distance, penutupan beberapa usaha yang berdampak kepada dirumahkannya karyawan (Kepramareni et al., 2020). tempat-tempat ibadah ditutup, transportasi publik dibatasi, hampir semua sektor layanan publik lainnya ditutup atau dibatasi jam operasionalnya (Pustakawan Madya \& Kementerian Sekretariat Negara, n.d.).

Penyebaran wabah Covid-19 memberikan dampak yang berimbas langsung terhadap penurunan secara drastis ekonomi UMKM (Khoiri Abdi \& Febriyanti, 2020). Wa1aupun banyak sekali yang guIung tikar, tidak menutup kemungkinan masih ada beberapa UMKM yang bertahan. Pelaku UMKM pada saat ini harus menghadapi masalah yang cukup besar dan diramalkan survei 47 persen UMKM berhenti berusaha, karena mengalami masalah kesehatan arus kas, sehingga harus merumahkan tenaga kerjanya (S. Wibowo, 2021).

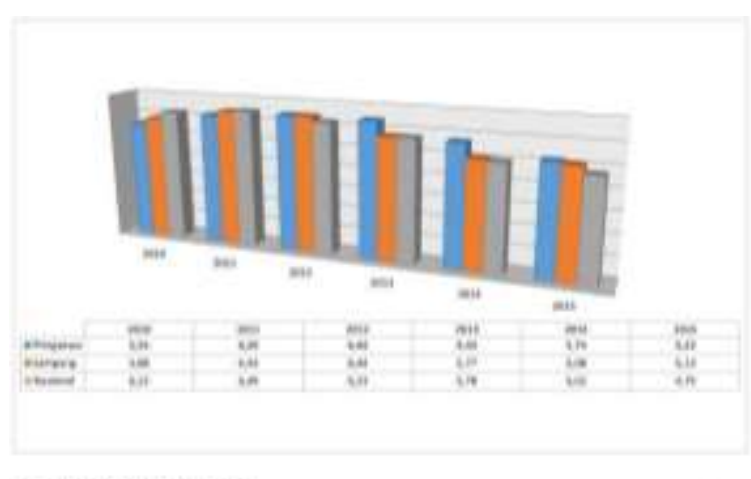

Gambar 1. Perbandingan LPE Nasiona1, Lampung, dan Kabupaten Pringsewu Tahun 2010-2015

Tidak hanya itu, Pemerintah Indonesia pun tidak tinggal diam dan merespon hal tersebut dengan ditetapkannya beberapa kebijakan nasional, diantaranya adalah seruan untuk bekerja dari rumah atau work from home (WFH), pemberlakuan social distancing dan pembatasan sosial berskala besar (PSBB) (Darmawan \& Atmojo, 2020). Maka dari itu, menyebabkan segala usaha terutama UMKM harus dapat menyesuaikan diri dengan keadaan yang baru akibat adanya pandemi Covid-19 (Januar Mahardhani, 2020). 
Kreatifitas dalam pengembangan di bisnis UMKM saat ini tentunya sangat diperlukan untuk membantu proses pengembangan UMKM kreatif (Darwanto, 2013) agar lebih semangat untuk menciptakan inovasi di masa pandemi ini sehingga akan membantu dalam pertumbuhan ekonomi dan agar dapat bertahan serta beradaptasi di masa pandemi Covid-19 ini. Apalagi dengan kaitannya di era industri 4.0 atau industri secara digital tentunya mencari peluang untuk inovasi, mengenali peluang, dan mengumpulkan informasi tentang peluang sangatlah besar. Seperti berjualan secara offline ataupun online melalui E-commerce (Mumuh et al., 2021) dengan memanfaatkan elektronik yang semakin canggih sehingga pemasaran meningkat dan juga tetap mempertimbangkan solusi yakni dengan protokol kesehatan yang ketat, berfokus untuk memenuhi kebutuhan sosial yang dasar, dan membangun ekosistem dan model bisnis baru dengan terciptanya keunggulan kompetitif (Halisa, 2020).

Inovasi juga bisa berupa menghasilkan produk yang berkualitas tetapi dengan biaya rendah (Merliana \& Kurniawan, 2016) dan penjualan yang sederhana tetapi efektif. Inovasi juga tak hanya terbatas pada strategi bisnisnya, tetapi juga bisa pada bentuk fisik produk itu sendiri. Sehingga potensi kreatif inilah memiliki prospek peluang yang menjanjikan. O1eh karena itu, jika sebuah bisnis yang sedang berjalan apabila tidak dapat bertahan lama di tengah masa pandemi ini ataupun berada di dalam persaingan jika saja pelaku usahanya ini minimnya pengetahuan tentang peluang usaha yang ada dan tidak memiliki inovasi untuk berkreatif. Oleh karena itulah sebagai pelaku bisnis harus bisa memotivasi dirinya sendiri sehingga dapat selalu kreatif dalam berinovasi dan mewujudkannya terutama di saat adanya krisis global seperti Pandemi virus Covid-19 sedang terjadi.

Dari total kurang lebih 1.500 UMKM se-Kabupaten Pringsewu, pelaku usahanya yang berada di sektor kuliner dan kerajinan tangan menjadi sektor usaha yang tidak terlalu terdampak pandemi Covid-19. Namun dengan adanya wabah tersebut para pelaku usaha ini harus memutar otak bagaimana agar UMKM yang dimilikinya tetap bertahan, maka para pemilik usaha tersebut harus mampu berinovasi dan berkreatifitas (Diandra, 2019).

Berdasarkan uraian diatas, penelitian ini bertujuan untuk mengetahui 1) UMKM mana di Kabupaten Pringsewu dapat bertahan di tengah pandemi Covid-19; 2) bagaimana inovasi dan kreatifitas yang dilakukan UMKM di Kabupaten Pringsewu agar dapat bertahan di tengah pandemi Covid-19.

\section{METODE PENELITIAN}

Metode yang digunakan dalam penelitian ini deskriptif kualitatif. Subjek dalam penelitian ini adalah 30 UMKM di Kabupaten Pringsewu. Penelitian dilakukan pada 1 maret sampai tanggal 30 maret 2021, sementara objeknya adalah masalah yang akan diteliti yaitu bagaimana kegiatan UMKM ini berinovasi, berkreatifitas dan dapat bertahan di tengah pandemi covid-19. Adapun Teknik pengumpulan data yang digunakan antara 1ain ada1ah wawancara dan dokumentasi.

\section{HASIL DAN PEMBAHASAN}

\section{UMKM yang Bertahan di Masa Pandemi}

Peran UMKM sangat1ah penting terutama saat pandemi virus Covid-19. Pentingnya UMKM sebagian besar berkaitan dengan tulang punggung ekonomi. UMKM memungkinkan perusahaan untuk 1ebih mudah beradaptasi terhadap suatu perubahan lingkungan. Maka dari itu, keberadaan UMKM menjadi penting sebagai penggerak kewirausahawan dan pembangunan ekonomi serta menjadi pencipta 1apangan kerja.

Berdasarkan observasi, ditemukan hasi1-hasi1 bahwa tidak semua UMKM yang ada di Pringsewu dapat bertahan 
dengan adanya wabah Covid-19. Hal ini disebabkan dari kurangnya moda1, minimnya penjualan dan dari segi pemasukan (Income) serta keuntungan bagi pengusaha berkurang secara drastic. Ada yang mengharuskan mengurangi jum1ah karyawan, ada juga dari pengusaha tersebut memilih tutup sementara waktu. Selain faktor-faktor tersebut, mobilitas yang harus dikurangi menjadi penyebabnya. Hal ini sangat berpengaruh terutama bagi pengusaha yang melakukan usaha door-todoor dari warung ke warung bahkan berkeliling untuk menjual produknya tersebut. Berikut data UMKM yang berhenti beroperasi:

Tabel 1. UMKM yang berhenti beroperasi

\begin{tabular}{ll}
\hline \multicolumn{1}{c}{ Nama UMKM } & \multicolumn{1}{c}{ Pemilik } \\
\hline Kopi Seribu & Wildan Ardabili \\
The Daun Kelor & Samsul Mu'arif \\
Pot Bunga Ban Bekas & Hapidin \\
Ternak Kelinci & Basuki Aziz \\
Keripik Pisang & Anjar Kuswanto \\
Tape Singkong & Juwadi \\
Keripik Singkong & Yuli Kusinah \\
\hline
\end{tabular}

Selain data tersebut, ditemukan bahwa ada juga UMKM yang mampu dan mau bertahan walau pemasukan sedikit, penjualan sulit namun mereka para pengusaha tersebut tetap mau bertahan. Berikut datanya :

Tabel 2. UMKM yang Bertahan

\begin{tabular}{ll}
\hline \multicolumn{1}{c}{ Nama UMKM } & \multicolumn{1}{c}{ Pemilik } \\
\hline Pengrajin Panahan & Amri Ma'ruf \\
$\begin{array}{l}\text { Pengrajin Kain Kaca } \\
\text { Kue Basah dan }\end{array}$ & Sunarno \\
Catering Makanan & \\
Catering Makanan & Supriyatini \\
Usaha Kuliner & Nurhayati \\
Pengrajin Perak & Musiatno \\
Usaha Salad Buah & Defi \\
Usaha Garam & Panut \\
Yodium Kue & Suratmi \\
Usaha Jamur & \\
Usaha & \\
Tradisional & Ari Sofian \\
Usaha Alpukat Kocok & Aundi \\
Peternak Jangkrik & Mulyono \\
Hotang & Tri \\
Bakso Pentol & Eva \\
\hline
\end{tabular}

\begin{tabular}{ll}
\hline Usaha Thai Tea & Soleh \\
Usaha Telor Asin & Rohmat \\
Kayu Olahan & Minanto \\
Pengrajin Karet & Suwenda \\
Martabak Mini & Anang Suherman \\
Kerajinan Bambu & Fa'idz \\
Kerajinan Tapis & Supriyati \\
Kopi Bubuk & Roni \\
\hline
\end{tabular}

Pendapatan dan kenaikan 1aba tidak terlalu mempengaruhi terhadap UMKM yang tidak mampu bertahan, disebabkan oleh bahan baku yang susah didapat, harga bahan pokok yang ikut naik, penjualan yang tidak menentu. Hal-hal tersebut bisa memicu barang tersedia di gudang tetapi penjualan kurang berkembang. Untuk UMKM yang bertahan dengan pendapatan yang cukup besar, ditambah keuntungan yang terus meningkat, mereka mampu melakukan inovasi dan kreatifitas dengan baik, mampu melihat bagaimana peluang terbaik yang bisa didapatkan, memanfaatkan momen penjualan yang bagus sehingga usaha mereka tetap bertahan.

Peneliti menyadari bahwa sebenarnya para pemilik UMKM dapat memiliki pendapatan yang cukup jika keuntungan perbulan stabi1, namun berdasarkan hasil oberservasi dan wawancara menyatakan bahwa ada beberapa pemilik UMKM yang pendapatannya cukup tapi tidak mampu bersaing da1am mempertahankan produknya, baik dari bahan, moda1, dan mengolah kemba1i keuntungannya.

UMKM yang ada di Pringsewu berada pada kategori UMKM Sektor Informal dan UMKM Mikro, yang artinya UMKM sektor informal dijalankan dalam golongan pedagang kaki lima yang mengandalkan gerobak atau stand-stand kecil sebagai tempat menjual barang produksinya. Sementara yang masuk kategori UMKM Mikro adalah UMKM dengan kemampuan sifat pengrajin namun kurang memiliki jiwa kewirausahaan untuk mengembangkan usahanya, karena banyak yang mempunyai usaha namun kurang cakap dalam menjual barang produksinya. 


\section{Bentuk Inovasi dan kreatifitas UMKM}

Sebagai salah satu sektor ekonomi yang paling penting, nafas terhadap UMKM perlu terus dilakukan terutama saat terjadinya pelemahan ekonomi di masa pandemi virus Covid-19 saat ini. Sehingga inovasi dan kreatifitas dibutuhkan di masa pandemi saat ini. Strategi pengusaha sebagai pelaku UMKM menjadi kunci dalam berinovasi dan meningkatkan kreatifitasnya agar usahanya bisa bertahan. Adanya inovasi dan kreatifitas ini diharapkan dapat mengantisipasi setiap bisnis atau kelompok usaha agar ekonomi di UMKM dapat tetap bertahan walaupun sedang mengalami pandemi serta menjadi pengembangan kualitas produk. Inovasi dan kreatifitas inilah yang mampu melakukan transformasi dan membangun harapan untuk bisa menghadapi dampak yang sedang terjadi.

Secara umum inovasi dan kreatifitas di da1am UMKM ini dapat mendukung usaha yang sudah ada atau bahkan memberi kesempatan dalam bisnis baru untuk memenuhi kebutuhan pasar. Dengan adanya inovasi dan kreatifitas ini juga berguna untuk menjaga agar setiap konsumen tidak cepat bosan dan tetap setia untuk selalu menggunakan produk yang ditawarkan. Jaringan yang terbentuk ini dapat tumbuh menjadi jaringan usaha yang besar dan dapat berdampak juga pada globalisasi kegiatan ekonomi ini. Dengan demikian, progress yang dituju akhirnya tercapai dengan dukungan pemanfaatan dan keleluasaan dalam kebijakan inovasi dan kreatifitas.

Pada masa pandemi yang sedang terjadi ini, banyak pelaku UMKM jalan di tempat, yang pada dasarnya belum memiliki kesiapan da1am menghadapi pandemi Covid-19 ini. Saat mengembangkan bisnis usahanya tidak maju karena minimnya inovasi dan kreatifitas serta hanya ikut-ikutan trend. Tanpa melihat potensi yang ada akhirnya usaha tersebut tidak bertahan 1ama dan kemudian bangkrut. Tidak heran jika produk UMKM lokal ini masih terbilang sedikit untuk mampu menembus pasar internasiona1.

Di saat masa pandemi yang belum pulih ini, bukan berarti tidak bisa membuat sebuah inovasi dan kreatifitas untuk bisnis yang sedang dijalankan. Maka dari itu, perusahaan harus menghasilkan inovasi dan kreatifitas yang sekreatif dan seefektif mungkin untuk meraih sukses. Tentunya di dalam inovasi dan kreatifitas ini dibutuhkannya motivasi yang kuat dan kreatifitas agar segala perubahan yang diciptakan dapat dilakukan dengan mudah. Motivasi ini bisa didapatkan dari diri sendiri maupun orang terdekat yang paling berpengaruh untuk diri sendiri dan kreatifitas yang kita dapat dengan bagaimana kita membuat suatu ide untuk memecahkan masa1ah yang ada. Maka dari itu, adanya permasalahan ekonomi di UMKM ini dengan adanya beberapa inovasi dan kreatifitas yang bisa kita lakukan untuk bertahan di masa pandemi, yaitu :

1. Berubahnya cara penjualan dari offline menjadi online
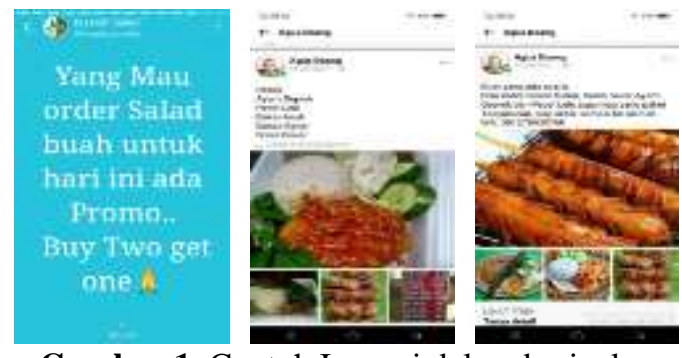

Gambar 1. Contoh Inovasi dalam berjualan

2. Membuat suatu produk baru yang benar-benar unik
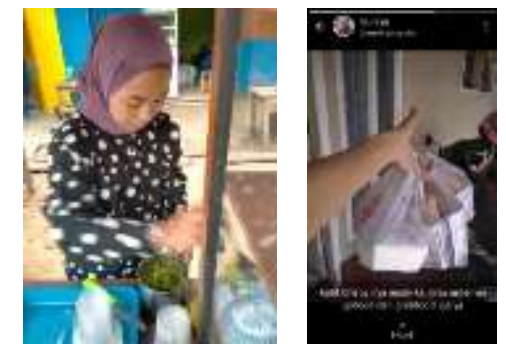

Gambar 2. Contoh kreatifitas dalam berjualan 
Untuk lebih lengkapnya, berikut uraian wawancara dari beberapa pemilik UMKM. sebagai berikut:

Tabel 3. Wawancara dengan pemilik UMKM Kopi Seribu

UMKM Kopi Seribu Bambu (Wi1dan Ardabili)

1 Bagaimana awa1 mu1a menja1ankan usaha tersebut?

Saya memulai usaha iini karena suka meminum kopi, terus saya juga memang punya kebun kopi, jadi niatnya hanya sekedar ingin berbagi rasa tadinya.

2 Adakah perbedaan atau inovasi dan kreatifitas yang dilakukan?

Perbedaannya dulu saya meracik kopi ditambah memakai irisan jahe yang disangrai dida1am wajan (roasting), jadi membuat kopinya itu terasa hangat di tubuh.

3 Apa yang membuat UMKM anda dapat bertahan atau tidak mampu bertahan?

Waktu itu lagi rame-ramenya usaha kopi, tapi berhubung saya hanya usaha keci1kecilan jadi 1ama-1ama tergerus juga, gulung tikar akhirnya.

4 Apakah di masa pandemic Covid-19 usaha anda tetap berja1 an ?

Saya sudah lama tidak memproduksi bubuk kopi untuk dijua1 1agi, se1ain kopi di kebun jarang berbuah, membeli kopi dari warga sekitar, terus mengolahnya sendiri, memasarkan sendiri tapi hasil kurang memuaskan jadi berhenti saja.

5 Bagaimana cara anda mengena1kan produk anda?

Datang ke warung-warung kecil untuk menitip kopi buatan saya.

6 Bagaimana cara anda menjua1 produk anda ?

Caranya dititipkan ke warung tersebut, terus nanti setelah seminggu saya ke warungwarung itu 1agi untuk mengecek apakah kopi sudah terjual, seka1ian mengisi lagi jika sudah habis, tapi yah namanya usaha ada untung ruginya.

7 Berapa pendapatan anda jika dihitung perbulan selama masa pandemic Covid-19 ?

Untuk penghasilan sebenernya gak tentu, kan ada yang jua1annya disini 1aku, disana belum tentu terjual karena gak cuma saya yang nitip kopi. Tapi ka1o ditaksir dulu itu perbulan sekitar Rp. 400.000 tambahan dari pendapatan pokok ka1o 1aku banyak.
Tabel 4. Wawancara dengan pemilik UMKM Kue Tradisional

UMKM Kue Tradisiona1 (Suratmi)

1 Bagaimana awal mula menjalankan usaha tersebut?

Sudah 1ama, karena ini usaha dari orangtua mas, saya hanya melanjutkan dan nambah mode1-mode1 yang berbeda aja.

2 Adakah perbedaan atau inovasi dan kreatifitas yang dilakukan?

Ya tadi itu mas, yang sudah ada tetap kita pakai, Cuma saya nambahin aneka kue, penambahan rasa dari buah-buahan biar kuekuenya ini ada warna dan rasa yang berbeda tapi kalo untuk pemanisnya tetap menggunakan pemanis alami dari gula bukan pakai sari manis.

3 Apa yang membuat UMKM anda dapat bertahan atau tidak mampu bertahan?

Ya segini mah A1hamduli11ah mas mampu dan cukup untuk bertahan, bersyukur aja masih dikasih ilmu pengetahuan jadi bisa nambahin aneka kue untuk di jua1.

4 Apakah dimasa pandemic Covid-19 usaha anda tetap berja1 an ?

Sampai saat ini A1hamduli1lah tetap jua1 an meski jualannya di kurangi.

5 Bagaimana cara anda mengenalkan dan menjual produk anda?

Tadinya Cuma di pasar-pasar aja, kan banyak yang ke pasar sambil belanja dan beli cemilan kue ini buat di rumah, tapi ka1au ada yang pesan misal buat yasinan gitu ya saya buatkan mas, tapi kan sekarang sudah modern misal ada yang pesen lewat te1fon gitu ya diterima, terus ya namanya juga jaman modern jadi ada gitu yang bikin foto-foto terus d sebar ke WAnya mas.

6 Berapa pendapatan anda jika dihitung perbulan se1ama masa pandemic Covid-19 ?

Ka1o pendapatan mah mas biasanya perbulan Rp. 500.000 udah bersih itu, moda1 untuk be1i bahan kue juga udah di potong dari pendapatan pas jualan, tapi ka1o misal pas bulan puasa ya bisa sampe Rp. 2.000.000 mas.

Tabel 5. Wawancara dengan pemilik UMKM Pengrajin Panahan

UMKM Pengrajin Panahan (Amri Ma'ruf)

1 Bagaimana awa1 mula menjalankan usaha tersebut? 
UMKM Pengrajin Panahan (Amri Ma'ruf)

Awa1nya pernah kerja ke 1uar kota mas, ikut temen 1ah terus sampe di kota salatiga jawa tengah, waktu disitu gak jauh ada tempat pengrajin panahan, iseng-iseng 1ah pas 1ibur main kesana, awa1nya ikut-ikutan terus nyoba, seneng gitu main panah, singkat cerita lah ya saya pulang dari merantau, lama itu kerja serabutan disini, terus pas lagi gak ada kerjaan itu ada pohon sawo di tebang sekitar tahun 2017an 1ah memulai usaha ini, nah dari pohon sawo itu sambi1 santai istirahat dirumah bikin 1 busur panah dan per1engkapannya dan jadilah saya punya panah buatan sendiri dirumah, dulu mau bawa dari jawa cumakan jauh mas susah juga bawanya.

2 Adakah perbedaan atau inovasi dan kreatifitas yang dilakukan?

Untuk perbedaannya sama aja dengan panah-panah tradisiona1 1ainnya, Cuma disini kekurangan kayu yang bagus misa1 sono keling gitu ka1o di jawa, jadi ya cobacoba buat pake kayu yang ada.

3 Apa yang membuat UMKM anda dapat bertahan atau tidak mampu bertahan?

Sejauh ini A1hamdu1i11ah bertahan, karena saya setelah itu membeli panahan untuk tambahan dirumah, terus sekitar awa1 2019 mulai membuka sejenis kursus panahan sampai sekarang.

4 Bagaimana cara anda mengena1kan produk anda?

Ditahun 2017 masih sendiri aja yang make mas, terus di awa1 2019 itu dari facebook mulai ik1anin posting-posting foto panahan dan kursus.

5 Bagaimana cara anda menjual produk anda ?

Untuk penjualan produk ada yang emang orang yang pernah kursus gitu lama-1ama kan pengen punya sendiri terus akhirnya be1i panah juga, tapi ya dari penjualan masih jarang yang pengen punya sendiri mas.

6 Berapa pendapatan anda jika dihitung perbulan selama masa pandemic Covid-19 ?

Pendapatannya ya dari hasi1 privat kursus memanah gitu dikenai biaya Rp. 150.000 perorang untuk member, ya misalkan ada 10 orang ya segitu penghasilannya, tapi jika ada orang yang ingin belajar sesekali ya kita kenai Rp. 50.000 untuk 2 jam kursus.

Berdasarkan hasi1 wawancara, usaha bapak wildan tutup karena kurangnya moda1, dari pasokan kopi dan tenaga karena hanya bekerja sendiri, memang niatnya hanya berbagi rasa tentang kopi, karena banyaknya persaingan dalam menjua1 kopi, walaupun penghasilannya 1umayan, kopi juga unik dengan penambahan jahe tapi rasa 1elah tak tebayarkan imbuhnya. Jika dianalisis, usaha ini sudah memiliki sebuah inovasi yaitu mencampurkan kopi dengan campuran jahe, sayangnya tidak diikuti dengan kreatifitas. Beliau tidak melakukan penjualan secara online yang seharusnya bisa mendorong hasil penjualannya meningkat karena bisa menjangkau konsumen lebih luas.

Berdasarkan hasil wawancara dengan ibu suratmi, didapat bahwa beliau tetap menggunakan rasa pemanis yang alami dan tidak menggunakan pemanis buatan atau sari manis. Dari segi inovasi yang dilakukannya adalah dengan menggunakan campuran rasa buah-buahan yang memiliki warna alami. Dari segi penghasilan, pendapatan bersih yang didapat ditaksir bisa mencapai Rp. 2.000.000, Rp. 500. 000 itu ka1au bu1an-bulan biasa (tanpa tambahan pesanan untuk yasinan dan hajatan), bahkan pada bulan puasa pendapatan bisa meningkat sampai Rp. 5.000.000. Pendapatan perbulan sudah menutup moda1, bahan baku mudah didapatkan dan melakukan penjualan secara online via Whatsapp membuat usahanya terus berja1an,

Berdasarkan hasi1 wawancara dengan pak amri, didapat bahwa pendapatannya dari usaha tersebut tidak menentu. Namun, hasi1 privat atau 1es memanah bisa didapat penghasilan mulai dari Rp. 50.000 sampai dengan Rp. 150.000 per orang. Sementara dari sektor penjualan alat-alat panahan masih jarang orang yang ingin memiliki, mungkin karena butuh pelatih agar tidak terjadi penyalahgunaan alat memanah tersebut. Pendapatan perbulan tergantung pada banyaknya member, jika member atau pengunjung bertambah maka pendapatanpun bertambah. Inovasinya yaitu membuat panahan dari kayu yang ada di 
sekitar rumahnya. Kreatifitasnya selain membuat panah, beliau juga membuka kursus memanah. Hal tersebutlah yang membuat usahanya terus berjalan.

\section{KESIMPULAN}

Berdasarkan analisis dan pembahasan, diperoleh kesimpulan bahwa dari 30 UMKM yang ada di Pringsewu, ada 7 UMKM yang tidak mampu bertahan dan sisanya masih berusaha bertahan. Hal tersebut se1ain karena adanya wabah covid19, para pengusaha ini memang mempunyai kenda1a da1am permodalan, pengolahan bahan produksi dan penjualan yang diperparah lagi saat kondisi pandemic seperti ini. Yang bisa mereka lakukan adalah menekan biaya produksi yang mengakibatkan pengurangan karyawan bahkan sampai menutup usahanya lebih cepat. sementara dari UMKM yang masih bertahan, alasannya disebabkan karena dari usaha tersebutlah sumber pengahasilan utama mereka, mau bagaimanapun hasi1nya, berapapun pendapatannya, mereka akan terus mempertahankan usahanya selagi belum ada jalan keluar 1 ain yang lebih menguntungkan.

Dalam hal Inovasi dan kreatifitas, ada beberapa hal yang dilakukan antara lain: berpindahnya cara berjualan dari offline menjadi online di masa pandemi, seperti menggunakan platform online, melakukan semua aktivitas bisnis dengan perencanaan yang baik untuk menyesuaikan antara produk-produk yang dihasilkan, meluncurkan pasar digita1 untuk memasarkan produk secara daring atau online. Kreatifitasnya yaitu, membuat suatu produk baru yang benar-benar unik, memodifikasikan produk yang menciptakan kualitas dan gaya baru untuk meningkatkan penjualan.

\section{DAFTAR PUSTAKA}

Bahtiar, R. A. (2021). Dampak Pandemi Covid-19 Terhadap Sektor Usaha Mikro, Kecil, dan Menengah Serta
Solusinya. Pusat Penelitian Badan Keahlian DPR RI, Bidang Ekonomi Dan Kebijakan Publik, 13(10), 1924.

https://berkas.dpr.go.id/puslit/files/inf o_singkat/Info Singkat-XIII-10-IIP3DI-Mei-2021-1982.pdf

Bakhri, S., \& Futiah, V. (2020). Pendampingan dan Pengembangan Manajemen Pemasaran Produk UMKM Melalui Teknologi Digital Di Masa Pandemi Covid-19. Jurnal Loyalitas Sosial: Journal of Community Service in Humanities and Social Sciences, 2(2), 59-70. https://doi.org/10.32493/jls.v2i2.p5970

Darmawan, E., \& Atmojo, M. E. (2020). Kebijakan Work from Home bagi Aparatur Sipil Negara di Masa Pandemi Covid-19. TheJournalish: Social and Government, 1(3), 92-99. http://thejournalish.com/ojs/index.php /thejournalish/article/view/26/15

Darwanto, D. danuar T. U. (2013). Pengembangan Usaha Mikro Kecil Dan Menengah (Umkm) Berbasis Ekonomi Kreatif Di Kota Semarang. Ilmu Ekonomi, 2(4), 1-13.

Darwis, D., Ferico Octaviansyah, A., Sulistiani, H., \& Putra, Y. R. (2020). Aplikasi Sistem Informasi Geografis Pencarian Puskesmas Di Kabupaten Lampung Timur. Jurnal Komputer Dan Informatika, 15(1), 159-170.

Diandra, D. (2019). Program pengembangan kewirausahaan untuk menciptakan pelaku usaha sosial yang kompetitif. Jurnal Administrasi Publik, 10(1), 1340-1347. https://jurnal.polban.ac.id/ojs3.1.2/proceeding/article/view/1424

Ernawati, S. (2021). Strategi Pengembangan Umkm Tenun Untuk Meningkatkan Sosial Ekonomi Di Kota Bima. PROSIDING SEMINAR NASIONAL EKONOMI DAN BISNIS 2021, 190-197. https://doi.org/10.32528/psneb.v0i0.5 
167

Halisa, N. N. (2020). Peran Manajemen Sumber Daya Manusia "Sistem Rekrutmen, Seleksi, Kompetensi dan Pelatihan" Terhadap Keunggulan Kompetitif: Literature Review. ADI Bisnis Digital Interdisiplin Jurnal, 1(2 Desember), 14-22. https://doi.org/10.34306/abdi.v1i2.16 8

Januar Mahardhani, A. (2020). Menjadi Warga Negara yang Baik pada Masa Pandemi Covid-19: Persprektif Kenormalan Baru. Jurnal Pancasila Dan Kewarganegaraan, 5(2), 65-76. https://doi.org/10.24269/jpk.v5.n2.20 20.pp65-76

Kepramareni, P., Suardhika, I. N., \& Jaya, I. M. K. (2020). Upaya Peningkatan Ekonomi Usaha Made Kaos Di Desa Kekeran Pada Masa Pandemi Covid19. Prosiding Seminar Regional Pengabdian Kepada Masyarakat Unmas Denpasar Di Masa Pandemi Covid-19 Tahun 2020. http://ejournal.unmas.ac.id/index.php/Prosidi ngCovid-19/article/view/1901

Khoiri Abdi, M., \& Febriyanti, N. (2020). Penyusunan Strategi Pemasaran Islam dalam Berwirausaha di Sektor Ekonomi Kreatif Pada Masa Pandemi Covid-19. El-Qist : Journal of Islamic Economics and Business (JIEB), 10(2), 160-178. https://doi.org/10.15642/elqist.2020.1 0.2.160-178

Merliana, V., \& Kurniawan, A. (2016). Pengaruh Strategi Biaya Rendah dan Diferensiasi terhadap Keberhasilan PT Tahu Tauhid. Jurnal Manajemen Maranatha, 15(2), 217-242. https://media.neliti.com/media/public ations/115455-ID-pengaruh-strategibiaya-rendah-dan-difer.pdf

Mumuh, L. A., Tangkau, J. E. M., \& Tala, O. Y. (2021). ANALISIS PENERAPAN PAJAK PENGHASILAN ONLINE MERCHANT PADA E-
COMMERCE DI KOTA MANADO. JAIM: Jurnal Akuntansi Manado, 2(3), 356-365.

Munthe, R. T. J., \& Rahadi, D. R. (2021). Inovasi dan Kreatifitas UMKM di masa Pandemi (Studi Kasus di kabupaten Bekasi). Jurnal Magisma, 9(1), 44-52.

Pustakawan Madya, \& Kementerian Sekretariat Negara. (n.d.). Working From Home ( WFH ) Untuk Fungsional Pustakawan Saat Pandemi Covid 19.

Rohmawati, A., \& Lestari, S. (2021). Pemetaan Peningkatan Kinerja UMKM Di Kabupaten Pesawaran Lampung Menggunakan Algoritma Naive Bayes. Seminar Nasional Hasil Penelitian Dan Pengabdian Masyarakat 2021, 1-5.

Sukwika, T. (2018). Peran Pembangunan Infrastruktur terhadap Ketimpangan Ekonomi Antarwilayah di Indonesia. Jurnal Wilayah Dan Lingkungan, 6(2), $\quad 115=130$. https://doi.org/10.14710/jwl.6.2.115130

Wardiningsih, R., Wahyuningsih, B. Y., \& Sugianto, R. (2021). Pelatihan Pengelolaan Keuangan Bagi Pelaku UMKM Penerima BPUM Sebagai Dampak Covid-19 Di Desa Jenggik Kecamatan Terara. Nusantara, 3(2), 258-266.

Wibowo, A. P., \& Sudiro, A. (2021). Perlindungan Hukum Terhadap Pekerja Dalam Pemutusan Hubungan Kerja (PHK) Dengan Alasan Efisiensi Akibat Pandemi Covid-19. To - Ra : Hukum Untuk Mengatur Dan Melindungi Masyarakat, 7(1), 135152.

Wibowo, S. (2021). Masker Kain sebagai Upaya Mengatasi Penyebaran COVID-19 dan Perekonomian UMKM di Sidoarjo. Abimanyu: Journal of Community Engagement, 2(2), 1-8. 